\title{
Peran Lembaga Manajemen Kolektif Sebagai Bentuk Perlindungan Hukum Pencipta Lagu Dan Pemilik Hak Terkait
}

\author{
Elly Hernawati
}

Fakultas Hukum Universitas Surabaya, hernawati.elly@gmail.com

\begin{abstract}
Copyright is one of the Intellectual Property Rights components and should be paid attention to. Even more in technology era that developing, copyright protection needed to be enhanced, so that the right of creator, Copyright holder or owner of relevant rights can be protected and urge people to create. Indirectly, good and healthy business climate could be fostered. Not all people have skill to create, that is why those people who have skill to create must be protected and even awarded, hoping that people urged to create. One of the creations that protected are song and music. In creating song or music, creator involve recording producer, music director or arranger. Regarding the creation, creator holds moral and economy rights, while parties involved hold the relevant rights to it.

Collective Management Agency is an agency that help creator or relevant rights owner in managing and distributing the creation which is song or music that being commercialized. Yet the creator must be the member of the agency beforehand. Commercialization of a song or music by user can rise problem. Protection to the song or music is for the whole thing, including lyric, notation, arrangement and song title. The utilization of a song or music should be still protecting the parties that hold the copyright and the relevant right to it.
\end{abstract}

Keywords: Collective Management Agency, Legal Protection

\section{Pendahuluan}

Hak Cipta merupakan bagian dari Hak Kekayaan Intelektual yang memegang peranan sangat penting dalam rangka menunjang Pembangunan Bangsa Indonesia, khususnya terkait dengan ilmu pengetahuan, seni dan sastra. Di sisi lain perkembangan ilmu pengetahuan, teknologi, seni dan sastra sudah demikian pesat, oleh karena itu dibutuhkan peningkatan perlindungan dan jaminan kepastian hukum bagi Pencipta, Pemegang Hak Cipta, maupun Pemilik Hak Terkait.

Perkembangan teknologi informasi dan komunikasi menjadi salah satu variabel dalam

Jurnal

YUSTIKA

Media Hubum dan Keadilan Fakultas Hukum Universitas Surabaya Vol. 22 No. 1, Juli 2019 E-ISSN: 2655-7479 melakukan penyempurnaan terhadap berbagai ketentuan peraturan perundang-undangan yang berlaku. Pengaturan mengenai Hak Cipta di Indonesia sebenarnya berawal dari berlakunya Auterswet 1912 pada masa Pemerintahan Hindia Belanda. Setelah Indonesia merdeka mengalami perubahan beberapa kali dan yang terakhir saat ini berlaku UndangUndang Nomor 28 Tahun 2014 tentang Hak Cipta (selanjutnya disebut UU Hak Cipta 2014) merupakan penyempurnaan dari Undang-Undang Nomor 19 Tahun 2002. Penggantian 
peraturan tersebut dimaksudkan untuk mengutamakan kepentingan nasional dan memperhatikan keseimbangan antara kepentingan Pencipta, Pemegang Hak Cipta dan Pemilik Hak Terkait. UU Hak Cipta 2014 ini berlaku terhadap:

a. semua Ciptaan dan produk Hak Terkait warga negara, penduduk, dan badan hukum Indonesia;

b. semua Ciptaan dan produk Hak Terkait bukan Warga Negara Indonesia, bukan Penduduk Indonesia dan bukan Badan Hukum Indonesia yang untuk pertama kali dilakukan pengumuman di Indonesia;

c. semua Ciptaan dan produk Hak Terkait dan Pengguna Ciptaan dan produk Hak Terkait bukan Warga Negara Indonesia, bukan Penduduk Indonesia, dan bukan Badan Hukum Indonesia dengan ketentuan :

1. negaranya mempunyai perjanjian bilateral dengan Negara Republik Indonesia mengenai perlindungan Hak Cipta dan hak terkait; atau

2. negaranya dan Negara Republik Indonesia merupakan pihak atau peserta dalam perjanjian multilateral yang sama mengenai perlindungan Hak Cipta dan Hak Terkait.

Pengertian Hak Cipta berdasarkan Pasal 1 angka 1 UU Hak Cipta 2014 adalah: "Hak eksklusif Pencipta yang timbul secara otomatis berdasarkan prinsip deklaratif setelah suatu Ciptaan diwujudkan dalam bentuk nyata tanpa mengurangi pembatasan sesuai dengan ketentuan peraturan perundang-undangan". Menurut Otto Hasibuan, mengenai Hak Cipta melekat beberapa sifat dasar sebagai berikut:

1. Hak Cipta adalah hak milik (property right);

2. Hak Cipta adalah hak yang terbatas waktunya (limited duration);

3. Hak Cipta adalah sebuah hak yang bersifat eksklusif (the exclusive right);

4. Hak Cipta adalah sebuah kumpulan hak di dalam sebuah karya (a multiple right, abundle of rights in one work). (Otto Hasibuan, 2014: 57)

Terkait dengan perlindungan terhadap Hak Cipta, terdapat salah satu Ciptaan yang masih menimbulkan permasalahan mengenai keberadaan kepemilikan hak dari masing-masing pihak yang terlibat di dalamnya, yaitu Ciptaan lagu dan/atau musik. Menurut Kamus Besar Bahasa Indonesia Musik itu identik dengan lagu artinya: "gubahan seni nada atau suara dalam urutan, kombinasi, dan hubungan temporal yang biasanya diiringi dengan alat musik untuk menghasilkan gubahan musik yang mempunyai kesatuan dan kesinambungan (mengandung irama)". Terciptanya suatu lagu dan/atau musik itu akan melibatkan berbagai pihak diantaranya: Pencipta, Pemegang Hak Cipta, Pemilik Hak Terkait, dalam hal ini meliputi: Penyanyi, Pemusik, Produser Rekaman, Penata Musik atau Pengaransemen maupun Lembaga Penyiaran.

Sebuah lagu dan/atau musik yang sudah terwujud, kemudian diperdengarkan dan menjadi diminati masyarakat, sebenarnya merupakan hasil peran dari siapa ?. Apakah Penciptanya, Penyanyinya atau Pemusiknya ataukah Pengarasemen, Produser Rekaman atau Lembaga Penyiaran. Masing-masing pihak tersebut secara tidak langsung mempunyai peranan di dalam keberhasilan suatu Ciptaan lagu dan/atau musik itu menjadi dikenal di masyarakat. Masing-masing pihak tersebut akan beranggapan bahwa Ciptaan lagu dan/atau musik yang beredar di masyarakat itu karena perannya dan bahkan menganggap bahwa sekaligus mempunyai Hak Cipta atas lagu tersebut.
Jurnal Yustika Vol. 22 No. 1, Jul 2019

Halaman | 38

Peran Lembaga Manajemen Kolektif Sebagai Bentuk Perlindungan Hukum Pencipta Lagu Dan Pemilik Hak Terkait

Elly Hernawati 
Jurnal Yustika

Vol. 22 No. 1, Jul 2019

Halaman I 39

Peran Lembaga

Manajemen

Kolektif Sebagai

Bentuk

Perlindungan

Hukum Pencipta

Lagu Dan Pemilik

Hak Terkait

Elly Hernawati
Seorang Pencipta membutuhkan suatu upaya dan pengorbanan untuk dapat mewujudkan Ciptaannya, sehingga sudah selayaknya namanya sebagai Pencipta itu melekat pada Ciptaannya dan siapapun wajib untuk menghargai jerih payah yang sudah dilakukan oleh Pencipta atas karya yang sudah diwujudkan tersebut. Keterlibatan seorang Penyanyi yang mempunyai suara bagus akan sangat mempengaruhi Ciptaan lagu dan/atau musik tersebut menjadi terkenal dan diminati masyarakat, tetapi sebaliknya apabila suara Penyanyi tersebut tidak bagus, maka berakibat lagu dan/atau musik itu tidak akan terkenal atau tidak diminati masyarakat. Pemusik juga sangat berperan terhadap suatu lagu dan/atau musik ketika diperdengarkan di masyarakat, sehingga apabila pada saat memainkan alat musiknya tidak profesional, dapat berakibat lagu dan/atau musik tersebut tidak laku di masyarakat. Termasuk juga Penata Musik atau Pengarasemen, dalam hal ini sangat berperan agar suatu lagu dan/atau musik itu menjadi lebih harmoni dan indah pada saat diperdengarkan. Demikian juga peran dari Produsen Rekaman akan sangat berarti pada saat Ciptaan lagu dan/atau musik itu diperdengarkan, artinya apabila rekamannya tidak bagus, maka dapat mengakibatkan masyarakat tidak berkeinginan untuk membeli rekaman tersebut. Sehubungan dengan itu pada umumnya masyarakat pada saat akan memilih suatu lagu dan/atau musik akan selalu melihat siapa Penciptanya, Penyanyinya, Penata musik atau Pengarasemennya, bahkan akan melihat siapa Produser Rekamannya. Hal ini menunjukkan bahwa suatu lagu dan/atau musik itu pada saat diwujudkan maupun diumumkan ke masyarakat selalu melibatkan peran dari berbagai pihak sebagaimana tersebut di atas.

Perlindungan terhadap berbagai pihak yang terlibat atas terwujudnya Ciptaan lagu dan/atau musik itu dapat menimbulkan permasalahan, mengingat di dalam Hak Cipta itu sendiri mencakup perlindungan terhadap 3 (tiga) hak yaitu: Hak Moral, Hak Ekonomi, dan Hak Terkait. Pengertian Hak Moral adalah hak yang melekat secara abadi pada diri Penciptanya, sedangkan Hak Ekonomi merupakan hak eksklusif Pencipta atau Pemegang Hak Cipta untuk mendapatkan manfaat ekonomi dari suatu Ciptaan. Pengertian Hak Terkait menurut Pasal 1 angka 5 UU Hak Cipta 2014 adalah Hak yang berkaitan dengan Hak Cipta yang merupakan hak eksklusif bagi Pelaku Pertunjukan, Produser Fonogram, atau Lembaga Penyiaran.

Perlindungan Hak Cipta mengarah pada 2 (dua) hal yaitu: aspek moral dan aspek ekonomi. Terkait dengan aspek moral, perlindungan terhadap Hak Cipta itu diperlukan untuk mendorong apresiasi pihak lain agar mau mencipta karena adanya suatu jaminan bahwa Ciptaan yang dihasilkan tersebut akan terlindungi. Hak Moral itu bersifat abadi, artinya Pencipta mendapatkan perlindungan atas reputasi dan integritas kreasi ciptaannya, oleh karena itu setiap orang mempunyai kewajiban untuk mengakui, menghargai serta menghormati Hak Moral tersebut. Sedangkan aspek ekonominya adalah membangun sikap masyarakat untuk menghargai hak seseorang atas Ciptaan yang sudah dihasilkannya dan pada akhirnya secara tidak langsung akan membentuk segmen pasar yang kuat. Bentuk menghargai hak seseorang itu berupa pemberian royalti apabila Ciptaan tersebut dimanfaatkan secara komersial, mengingat realisasi suatu karya cipta itu membutuhkan kemampuan waktu, tenaga, maupun biaya. Perlindungan terhadap kedua aspek tersebut menunjukkan adanya keseimbangan antara kepentingan Pencipta dan pihak-pihak yang terkait di dalamnya serta kepentingan masyarakat terutama kepentingan nasional. Pelanggaran terhadap Hak Moral dan Hak Ekonomi Pencipta, dan Pemilik Hak Terkait dapat mengikis motivasi para Pencipta dan Pemilik hak Terkait untuk mau berkreasi atau mencipta kembali. 
Ciptaan lagu dan/atau musik menjadi komoditi industri yang mempunyai nilai tinggi dan di dalam perkembanganya Ciptaan tersebut banyak dimanfaatkan oleh berbagai pihak melalui berbagai sarana dengan tujuan untuk mendapatkan keuntungan, contohnya: pemutaran lagu di pusat-pusat pembelanjaan, gedung bioskop, karaoke, cafe-cafe, internet, televisi, rumah produksi, dan tempat-tempat yang lain. Pemanfaatan Ciptaan lagu dan/atau musik secara komersial tersebut dilakukan tanpa ijin dari Pencipta, Pemegang, maupun Pemilik hak Terkait. Hal ini merupakan salah satu bentuk pelanggaran terhadap kepemilikan Ciptaan lagu dan/atau musik tersebut. Pelanggaran terhadap keberadaan Ciptaan lagu dan/atau musik tersebut tidak hanya merugikan Pencipta, akan tetapi juga Pemegang Hak Cipta dan bahkan pada pihak-pihak yang memiliki Hak Terkait.

Pemanfaatan Ciptaan lagu dan/atau musik oleh pihak lain, baik dalam hal pengumuman (performing rights) atau penggandaan (mechanical rights) dapat dilakukan oleh siapapun baik perseorangan maupun suatu badan hukum dengan wilayah dan waktu yang relatif tidak bisa diketahui oleh Pencipta maupun Pemilik Hak Terkait itu sendiri. Terhadap Ciptaan lagu dan/atau musik yang dimanfaatkan secara komersial oleh pihak lain tersebut, seorang Pencipta maupun Pemilik Hak Terkait akan mengalami kesulitan dalam melakukan pengawasan terhadap Ciptaannya yang telah dimanfaatkan oleh berbagai pihak tersebut tanpa ijin, khususnya terkait dengan pembayaran mengenai besarnya royalti yang seharusnya menjadi hak dari seorang Pencipta mapun Pemilik Hak Terkait.

\section{Pembahasan}

\subsection{PERLINDUNGAN HUKUM PADA PENCIPTA DAN PEMILIK HAK TERKAIT ATAS LAGU DAN/ATAU MUSIK}

Lagu menurut Ensiklopedia Indonesia adalah suatu kesatuan musik yang terdiri atas susunan pelbagai nada yang berurutan. Setiap lagu ditentukan oleh panjang pendek dan tinggi rendahnya nada-nada tersebut; di samping itu irama juga memberi corak tertentu kepada sebuah lagu. (Otto Hasibuan, 2014: 139). Sebuah lagu terdiri dari beberapa unsur yaitu: melodi, lirik, aransemen, dan notasi. Melodi adalah suatu deretan nada yang karena kekhususan dalam penyusunan menurut jarak dan tinggi nada, memperoleh suatu watak tersendiri dan menurut kaidah musik yang berlaku membulat jadi suatu kesatuan organik. Lirik adalah syair atau katakata yang disuarakan mengiringi melodi. Aransemen adalah penataan terhadap melodi. Notasi adalah penulisan melodi dalam bentuk not balok atau not angka. (Otto Hasibuan;2014:140) Pengertian musik menurut Ensiklopedia Indonesia adalah suara yang disusun demikian rupa sehingga mengandung irama, lagu, dan keharmonisan terutama dari suara yang dihasilkan dari alat-alat yang dapat menghasilkan irama. Sedangkan dalam UU Hak Cipta 2014 mengenai pengertian lagu dan musik tidak ada perbedaan. Hal ini tertuang di dalam ketentuan UU Hak Cipta 2014 Pasal 40 ayat (1) huruf d menentukan sebagai berikut : "lagu dan/atau musik diartikan sebagai satu kesatuan karya cipta yang bersifat utuh".

Pada dasarnya sebuah lagu dan/atau musik merupakan suatu karya intelektual yang diwujudkan atas dasar kualitas rasa, karsa dan kemampuan seseorang. Keahlian dalam mencipta lagu dan/atau musik itu tidak banyak dimiliki oleh setiap manusia, semua itu karena karunia dan anugerah yang diberikan Tuhan kepada seorang manusia dan hal itu menjadikan suatu kelebihan yang dimiliki oleh seseorang. Sehubungan dengan itu sudah sepantasnya menjadi suatu kewajiban bagi siapapun untuk memberikan penghargaan atas karya cipta 
Jurnal Yustika

Vol. 22 No. 1, Jul 2019

Halaman | 41

Peran Lembaga

Manajemen

Kolektif Sebagai

Bentuk

Perlindungan

Hukum Pencipta

Lagu Dan Pemilik

Hak Terkait

tersebut dan diharapkan tidak ada yang melanggar Hak Cipta tersebut. Menurut ST Stewart Hak Cipta itu perlu dilindungi dan dihargai dengan alasan sebagai berikut:

1. Alasan keadilan (the principle of nature justice). Seorang Pencipta dalam mengekspresikan karyanya perlu dipublikasikan, tetapi sekaligus mencegah kerugian atau perusakan karya intelektualnya. Royalti yang diterimanya merupakan upah dari karya intelektualnya.

2. Alasan ekonomi (the economic argument). Suatu investasi sangat dibutuhkan untuk membuat suatu kreasi. Investasi tidak akan ada jika jika tidak ada harapan ganti rugi atau untung.

3. Alasan budaya (the cultural argument). Karya yang dihasilkan Pencipta merupakan aset nasional, oleh karena itu dorongan untuk melakukan kreativitas merupakan kontribusi pembangunan budaya nasional.

4. Alasan sosial (the social argument). Penyebaran karya-karya akan membentuk hubungan antar kelompok rasial, kelompok usia, sehingga akan menciptakan perpaduan sosial. Penyebaran tersebut akan memberikan kontribusi terhadap kemajuan sosial. (Otto Hasibuan, 2014: 55)

Pengertian Hak Cipta terdapat di dalam ketentuan Pasal 1 angka 1 UU Hak Cipta 2014 sebagai berikut: "Hak Eksklusif Pencipta yang timbul secara otomatis berdasarkan prinsip Deklaratif setelah suatu ciptaan diwujudkan dalam bentuk nyata tanpa mengurangi pembatasan sesuai dengan ketentuan peraturan perundang-undangan". Memperhatikan pengertian tersebut dapat dikatakan bahwa berdasarkan prinsip Deklaratif menunjukkan bahwa Hak Cipta itu tidak mengharuskan adanya suatu pendaftaran karena bagi seseorang yang melakukan pendaftaran hanya dianggap sebagai pemakai pertama atas ciptaannya, dalam arti posisi tersebut menjadi gugur apabila ada pihak lain (meskipun tidak melakukan pendaftaran) dapat membuktikan bahwa yang bersangkutan sebagai pemakai pertama atas ciptaan yang sama tersebut. Seseorang akan dilindungi haknya atas Ciptaan pada saat sudah dituangkan dan diwujudkan dalam suatu bentuk dan bersifat asli/orisinalitas, dalam arti tidak meniru pihak lain. Terhadap Pencipta yang melakukan pendaftaran ataupun yang tidak melakukan pendaftaran, sama-sama mendapatkan perlindungan dan terhadap Ciptaan yang sama akan dibuktikan siapa yang mencipta pertama kali.

Pemahaman bahwa Hak Cipta merupakan Hak Eksklusif terdapat di dalam Penjelasan Pasal 4 UU Hak Cipta 2014 sebagai berikut: "Hak yang hanya diperuntukkan bagi Pencipta, sehingga tidak ada pihak lain yang dapat memanfaatkan hak tersebut tanpa ijin Pencipta. Sedangkan pengertian Pencipta berdasarkan Pasal 1 angka 4 UU Hak Cipta 2014 adalah: "Seorang atau beberapa orang yang secara sendiri-sendiri atau bersama-sama menghasilkan suatu Ciptaan yang bersifat khas dan pribadi". Pemahaman mengenai siapa yang disebut dengan Pencipta atau Pemegang hak Cipta itu dapat mencakup 2 (dua) hal yaitu:

(1) Pencipta sekaligus sebagai Pemegang Hak Cipta apabila Ciptaan itu tidak dialihkan kepada pihak lain;

(2) Pencipta berbeda dengan Pemegang Hak Cipta apabila Ciptaan itu dialihkan kepada pihak lain, maka ada yang disebut Pencipta dan ada Pemegang Hak Cipta.

Hal ini tercermin di dalam pengertian Pemegang Hak Cipta sebagaimana ketentuan di dalam Pasal 1 angka 4 UU Hak Cipta 2014 ialah sebagai berikut: "Pemegang Hak Cipta adalah Pencipta sebagai Pemilik Hak Cipta, pihak yang menerima hak tersebut secara sah dari 
Pencipta, atau pihak lain yang menerima lebih lanjut hak dari pihak yang menerima hak tersebut secara sah".

Jurnal Yustika

Pencipta mempunyai Hak Moral dan Hak Ekonomi, sedangkan Pemegang Hak Cipta yang bukan Pencipta hanya memiliki sebagian dari Hak Eksklusif berupa Hak Ekonomi. Hal ini menunjukkan bahwa Hak Cipta itu mengandung esensi monopoli atas Hak Moral dan Hak Ekonomi. Terkait dengan Hak Moral, Henry Soelistyo berpendapat bahwa Hak Moral itu mencakup 2 (dua) hal yaitu: Hak Paterniti (right of paternity) dan Hak Integritas (right of integrity). Mengenai Hak Paterniti yang esensinya mewajibkan nama Pencipta disebut atau dicantumkan dalam Ciptaan. Sedangkan Hak Integritas berhubungan dengan segala bentuk sikap dan perlakuan yang terkait dengan integritas atau martabat Pencipta. Dalam pelaksanaannya hak tersebut diekspresikan dalam bentuk larangan untuk mengubah, mengurangi, atau merusak ciptaan yang dapat menghancurkan integritas Penciptanya. (Henry Soelistyo, 2011: 16)

Hak Moral merupakan suatu hak yang melekat secara abadi pada diri Penciptanya, sebagaimana diatur dalam pasal 5 ayat (1) UU Hak Cipta 2014 meliputi hal-hal sebagai berikut:

1. Tetap mencantumkan atau tidak mencantumkan namanya pada salinan sehubungan dengan pemakaian ciptaannya untuk umum;

2. Menggunakan nama aliasnya atau samarannya;

3. Mengubah ciptaannya sesuai dengan kepatutan dalam masyarakat;

4. Mengubah judul dan anak judul ciptaan; dan

5. Mempertahankan haknya dalam hal terjadi distorsi ciptaan, mutilasi ciptaan, modifikasi ciptaan, atau hal yang bersifat merugikan kehormatan diri atau reputasinya.

Penjelasan dari Pasal tersebut menentukan bahwa yang dimaksud dengan 'distorsi Ciptaan' adalah: tindakan pemutarbalikkan suatu fakta atau identitas. Sedangkan yang dimaksud dengan 'mutilasi Ciptaan' adalah: proses atau tindakan menghilangkan Ciptaan. Demikian juga yang dimaksud 'modifikasi Ciptaan' adalah: pengubahan atas Ciptaan. Terhadap Hak Moral ini, tidak dapat dialihkan selama Pencipta masih hidup, akan tetapi apabila Pencipta sudah meninggal dunia, maka pelaksanaan Hak Moral tersebut dapat dialihkan dengan wasiat atau karena sebab lain sesuai dengan peraturan perundang-undangan yang berlaku.

Pada Ciptaan lagu dan/atau musik, Hak Moral Pencipta itu ada pada saat sebuah karya lagu dan/atau musik tersebut sudah terwujud bentuknya (psycal form) dan mempunyai keaslian (original), hal ini dikarenakan Hak Cipta atas lagu dan/ atau musik itu ada, sejak Ciptaan Lagu dan/atau musik tersebut sudah nyata terwujud dan menunjukkan keaslian. Tidak diharuskan untuk melakukan pendaftaran atas Ciptaan tersebut, artinya perlindungan sebuah Ciptaan lagu dan/atau musik itu dapat diberikan kepada Pencipta baik yang melakukan pendaftaran maupun yang tidak melakukan pendaftaran, artinya keduanya samasama mempunyai kesempatan untuk mendapatkan perlindungan hukum sepanjang dapat pihak-pihak tersebut dapat membuktikan siapa yang mewujudkan Ciptaan itu pertama kali dalam bentuk yang nyata dan bersifat originalitas.

Sebuah lagu dan/atau musik yang sudah selesai liriknya diciptakan oleh Penciptanya, akan melibatkan pihak-pihak lain agar lagu dan/atau musik tersebut dapat diperedengarkan dan dapat dimanfaatkan oleh masyarakat. Salah satu pihak yang terlibat adalah Produser Rekaman Suara yaitu: merekam Ciptaan lagu dan/atau musik dalam berbagai bentuk, misalnya: kaset, CD, VCD dan sebagainya. Selanjutnya Produser Rekaman Suara akan melibatkan Penata Musik atau Pengaransemen untuk membuat aransemen atas lagu dan/atau
Vol. 22 No. 1, Jul 2019

Halaman | 42

Peran Lembaga Manajemen

Kolektif Sebagai Bentuk

Perlindungan

Hukum Pencipta

Lagu Dan Pemilik Hak Terkait

Elly Hernawati 
Jurnal Yustika

Vol. 22 No. 1, Jul 2019

Halaman | 43

Peran Lembaga

Manajemen

Kolektif Sebagai

Bentuk

Perlindungan

Hukum Pencipta

Lagu Dan Pemilik

Hak Terkait

Elly Hernawati musik tersebut. Pada saat lagu dan/atau musik disuarakan dibutuhkan seorang Penyanyi dan Pemusik. Kedudukan pihak-pihak tersebut sangat membantu keberhasilan atau ketenaran sebuah Ciptaan lagu dan/atau musik itu di mata masyarakat. Tanpa pihak-pihak tersebut sebaik apapun lirik dan notasi musik yang dibuat Pencipta, belum tentu lagu dan/atau musik tersebut diminati oleh masyarakat. Pihak-pihak tersebut di dalam UU Hak Cipta 2014 disebut sebagai Pemilik Hak Terkait.

Pengertian Hak Terkait diatur dalam Pasal 1 angka 5 UU Hak Cipta 2014 sebagai berikut: "hak yang berkaitan dengan Hak Cipta yang merupakan Hak Ekslusif bagi Pelaku Pertunjukan, Produser Fonogram, atau Lembaga Penyiaran". Pengertian Pelaku Pertunjukkan adalah: "seseorang atau beberapa orang yang secara sendiri-sendiri atau bersama-sama menampilkan dan mempertunjukkan suatu Ciptaan". Sedangkan Produser Fonogram adalah: "orang atau badan hukum yang pertama kali merekam dan memiliki tanggung jawab untuk melaksanakan perekaman suara atau perekaman bunyi, baik perekaman pertunjukan maupun perekaman suara atau bunyi lain". Pemahaman mengenai Lembaga Penyiaran terdapat dalam Pasal 1 angka 8 UU Hak Cipta 2014 yaitu: "penyelenggaraan penyiaran, baik Lembaga Penyiaran Publik, Lembaga Penyiaran Swasta, Lembaga Penyiaran Komunitas maupun Lembaga Penyiaran Berlangganan yang dalam melaksanakan tugas, fungsi, dan tanggung jawabnya sesuai dengan ketentuan peraturan perundang-undangan".

Semua yang terlibat sebagaimana tersebut di atas, masing-masing mempunyai hak atas sebuah Ciptaan lagu dan/atau musik, misalnya: Produser Rekaman Suara di dalam UU Hak Cipta 2014 disebut Produser Fonogram mempunyai Hak Terkait yang berupa Hak Ekonomi. Penyanyi dan Pemusik, di dalam UU Hak Cipta 2014 disebut Pelaku Pertunjukan mempunyai Hak Terkait yang berupa Hak Ekonomi, sedangkan Penata Musik atau Pengaransemen pada UU Hak Cipta 2014 tidak disebutkan dengan jelas pengaturannya. Hanya saja perlu diketahui bahwa pengertian lagu dan/atau musik itu sebenarnya merupakan satu kesatuan yang utuh, sehingga dapat dikatakan bahwa pengaransemenan suatu lagu itu sebenarnya merupakan bagian dari Ciptaan lagu dan/atau musik sebagaiman pendapat di bawah ini:

"Aransemen adalah gubahan lagu untuk orkes atau kelompok paduan musik, baik secara vokal maupun instrumental. Penataan musik atau pengerjaannya bukan hanya sekedar perluasan teknis, namun juga menyangkut pencapaian nilai artistik yang dikandungnya. Aransemen sering disingkat Arr. Seorang arranger atau penata musik dapat menggubah dengan gaya atau selera masing-masing aransemen vokal dapat dibawakan dalam bentuk duet, trio, ansambel, maupun orkes. Aransemen yang baik perlu ketekunan dalam berlatih. Seorang arranger harus mengerti benar tentang melodi serta karakternya, serta harmoni dan ilmunya. Salah satu ilmu yang dipakai dalam mengaransemen adalah ilmu harmoni. Harmoni adalah ilmu tentang keselarasan bunyi. Dengan menguasai ilmu harmoni seseorang akan dapat membuat paduan-paduan nada dengan baik". (Senibudayaku, 2017)

Sebuah lagu dan/atau musik itu seringkali berubah-ubah aransemennya, sehingga tampilan dan suara terlihat ada perbedaan antara aransemen yang dibuat oleh Penata Musik atau Pengaransemen yang satu dengan lainnya. Sehubungan dengan itu seharusnya terhadap Penata Musik atau Pengaransemen juga mendapatkan penghargaan atas haknya dalam mengaransemen sebuah lagu, karena dengan keahlian dan kreativitasnya seorang Penata Musik atau Pengaransemen telah membuat suatu aransemen sehingga menyebabkan lagu dan/atau musik tersebut nampak berbeda antara satu dengan yang lain. Untuk itu tidak tepat 
apabila mengabaikan karya yang sudah dibuat oleh Penata Musik atau Pengaransemen dalam rangka untuk memperindah dan melengkapi sebuah lagu dan/atau musik yang sudah diciptakan oleh Penciptanya tersebut.

Sebuah lagu dan/atau musik yang diumumkan akan selalu menampilkan siapa Penciptanya dan Penata Musik atau Pengaransemennya. Apabila lagu dan/atau musik tersebut Pencipta dan Penata Musik atau Pengaransemennya itu sama orangnya, maka tidak menimbulkan permasalahan, akan tetapi kalau kedua pihak tersebut adalah orang yang berbeda maka akan kesulitan dalam menentukan Hak Moral atas Ciptaan lagu dan/atau musik tersebut. Seorang Pencipta mempunyai Hak Moral dan sekaligus Hak Ekonomi atas lagu dan/atau musik yang diciptakannya, sedangkan Penata Musik atau Pengaransemen tidak mempunyai Hak Moral atas lagu dan/atau musik yang diciptakan oleh Penciptanya, tetapi hanya mempunyai Hak Moral dan Hak Ekonomi atas aransemen yang ada pada lagu dan/atau musik tersebut. Secara tidak langsung tujuan membuat aransemen itu pada dasarnya adalah untuk memberikan warna dan esensi pada lagu dan/atau musik tersebut, agar terdengar lebih indah dan bahkan memiliki warna yang berbeda antara aransemen yang satu dengan aransemen yang kemudian. Oleh karena itu dapat dikatakan bahwa kegiatan pengaransemen itu merupakan suatu kesatuan dari lagu dan/atau musik sebelum diperdengarkan.

Keterlibatan Penata Musik atau Pengaransemen dalam sebuah lagu dan/atau musik yang diciptakan oleh Penciptanya pada dasarnya merupakan pihak-pihak yang ikut berperan di dalam terwujudnya sebuah lagu dan/atau musik, karena dengan keterlibatannya dapat mengakibatkan lagu dan/atau musik itu menjadi harmoni, indah serta enak didengar. "Pengertian harmoni adalah ilmu untuk menyusun akor-akor, atau disebut juga paduan nada. Dengan harmoni akan memiliki bentuk dan struktur, sehingga akan menghasilkan suatu komposisi atau lagu yang bermakna" (Kompasiana, 2010). Dengan demikian Penata Musik atau Pengaransemen dapat dikatakan sebagai pihak yang mempunyai peranan penting dalam terwujudnya lagu dan/atau musik. Keberadaan pihak-pihak tersebut tidak diatur di dalam UU Hak Cipta 2014, termasuk perlindungan terhadap hak yang seharusnya diperoleh apabila sebuah lagu dan/atau musik itu dimanfaatkan oleh pihak lain dengan cara dikomersialkan. Mengingat pentingnya suatu aransemen pada suatu lagu dan/atau musik, semestinya pihak Pengaransemen dapat dikatakan mempunyai Hak Moral dan Hak Ekonomi atas aransemennya, karena tanpa terlibatnya pihak Pengarensemen dapat mengakibatkan lagu dan/atau musik itu tidak punya harmoni, tidak artistik atau ibaratnya aransemen itu rohnya suatu Ciptaan lagu dan/atau musik.

Hak Ekonomi merupakan hak eksklusif Pencipta atau Pemegang Hak Cipta untuk mendapatkan manfaat ekonomi atas ciptaan. Pemanfaatan terhadap Hak Ekonomi tersebut berdasarkan ketentuan Pasal 9 UU Hak Cipta 2014 menyangkut hal-hal sebagai berikut:
a. Penerbitan ciptaan;
b. Penggandaan ciptaan dalam segala bentuknya;
c. Penerjemahan ciptaan;
d. Pengadaptasian, pengaransemenan, atau pentransformasian ciptaan;
e. Pendistribusian ciptaan atau salinannya;
f. Pertunjukan ciptaan;
g. Pengumuman ciptaan;
h. Komunikasi ciptaan;
i. Penyewaan ciptaan.

Jurnal Yustika Vol. 22 No. 1, Jul 2019

Halaman | 44

Peran Lembaga Manajemen Kolektif Sebagai Bentuk Perlindungan Hukum Pencipta Lagu Dan Pemilik Hak Terkait

Elly Hernawati 
Jurnal Yustika

Vol. 22 No. 1, Jul 2019

Halaman | 45

Peran Lembaga

Manajemen

Kolektif Sebagai

Bentuk

Perlindungan

Hukum Pencipta

Lagu Dan Pemilik

Hak Terkait

Elly Hernawati
Sehubungan dengan Ciptaan lagu dan/atau musik, seorang Pencipta mempunyai Hak Ekonomi meliputi:

1. Hak merekam (the mechanical right);

2. Hak memperbanyak (the reproduction right):

a. Memperbanyak secara mekanis (mechanical reproduction);

b. Memperbanyak secara cetak/tertulis (printing reproduction);

c. Memperbanyak untuk karya audio visual (synchronization);

3. Hak mengalihwujudkan (the adaptation right);

4. Hak menyiarkan (the broadcasting and cablecasting right) atau hak mengumumkan (the performing right);

5. Hak menjual (the selling right);

6. Hak mengedarkan (the distribution right);

7. Hak menyebarkan (the publication right);

Menurut WIPO Performance and Phonograms Treaty 1996 (selanjutnya disingkat WPPT), yang telah diratifikasi Pemerintah Indonesia melalui Keputusan Presiden Republik Indonesia Nomor 74 Tahun 2004, mengenai hak-hak Pelaku, termasuk dalam hal ini seorang penyanyi, mempunyai Hak Moral dan Hak Ekonomi. Inti dari Hak Moral Pelaku adalah hak untuk disebut namanya atau dinyatakan sebagai Pelaku atas karya pertunjukannya. Sementara untuk Hak Ekonomi Pelaku, WPPT menjabarkannya dalam 4 (empat) macam hak, sebagai berikut :

1. Hak Reproduksi, adalah hak khusus untuk melarang atau memberi izin penggandaan dalam segala bentuk dan cara, baik langsung maupun tidak langsung, karya pertunjukan yang telah diwujudkan dalam rekaman;

2. Hak Distribusi, adalah hak untuk melarang atau memberi izin untuk menyediakan rekaman pertunjukan asli atau salinannya kepada masyarakat baik melalui cara-cara pengalihan pemilikan lainnya, baik yang dikaitkan dengan saat pertama kali dilakukan penjualan atau pengalihan kepemilikan rekaman asli atau salinannya, dengan persetujuan pelaku;

3. Hak Sewa, adalah hak untuk melarang atau memberi izin penyewaan secara komersial rekaman asli karya pertunjukan atau salinannya sesuai dengan ketentuan sebagaimana ditetapkan peraturan perundang-undangan nasional. Hal serupa berlaku sekalipun rekaman karya pertunjukan telah diedarkan dengan persetujuan pelaku;

4. Hak memberi kuasa untuk disajikan kepada publik, adalah hak untuk melarang atau memberi izin untuk menyediakan rekaman pertunjukan, baik dengan menggunakan peralatan dengan kabel atau tanpa kabel dengan cara sedemikian rupa sehingga setiap orang dapat menikmatinya dari tempat dan waktu yang dipilihnya sendiri. (Landasan Teori, 2015)

Diantara beberapa Hak Ekonomi Pencipta sebagaimana tersebut di atas, terdapat hakhak yang sangat penting yang mempengaruhi kepemilikan hak atas Ciptaan lagu dan/atau musik yang beredar di masyarakat, akan tetapi hak-hak tersebut seringkali menimbulkan permasalahan sebagai berikut:

a. Hak Pengumuman atas Ciptaan. (performing rights)

b. Hak Penggandaan atas Ciptaan. (mechanical rights)

\section{Ad. a. Hak Pengumuman atas Ciptaan.}


Arti kata 'pengumuman' menurut Kamus Besar Bahasa Indonesia adalah: "proses, cara, perbuatan mengumumkan, pemberitahuan". Pengertian 'pengumuman' di dalam UU Hak Cipta 2002 diatur dalam Pasal 1 angka 5 sebagai berikut: "pembacaan, penyiaran, pameran, penjualan, pengedaran, atau penyebaran suatu Ciptaan dengan menggunakan alat apapun, termasuk media internet, atau melakukan dengan cara apapun sehingga suatu Ciptaan dapat dibaca, didengar, atau dilihat orang lain".

Berlakunya UU Hak Cipta 2014, pengertian 'pengumuman' terdapat dalam Pasal 1 angka 11 sebagai berikut: "pembacaan, penyiaran, pameran, suatu ciptaan dengan menggunakan alat apapun baik elektronik atau non elektronik atau melakukan dengan cara apapun sehingga suatu ciptaan dapat dibaca, didengar, atau dilihat orang lain". Pengaturan mengenai pengertian 'pengumuman' di dalam UU Hak Cipta perlu ada, mengingat adanya Hak Cipta pada seseorang itu bukan karena adanya pendaftaran, akan tetapi karena diumumkan pertama kali dalam bentuk yang nyata dan ada keasilan atau originalitas. Hal ini tersirat di dalam pengertian Hak Cipta dalam Pasal 1 angka 1 UU Hak Cipta 2014 menentukan sebagai berikut: "Hak Cipta adalah Hak Eksklusif Pencipta yang timbul otomatis berdasarkan Prinsip Deklaratif setelah suatu Ciptaan diwujudkan dalam bentuk nyata tanpa mengurangi pembatasan sesuai dengan ketentuan peraturan perundang-undangan".

Menurut Rooseno Harjowidagdo, terdapat beberapa cara pengumuman Ciptaan yaitu:

1. Pengumuman Ciptaan melalui penyiaran radio, sehingga Ciptaan hanya dapat didengar saja oleh orang lain (biasanya dilakukan oleh para user, misalnya: siaran radio, pub, karaoke, rumah makan, restoran, jasa penerbangan, dan hotel);

2. Pengumuman Ciptaan melalui media penyiaran televisi, sehingga Ciptaan dapat didengar dan dilihat oleh orang lain;

3. Pengumuman Ciptaan melalui media cetak, sehingga Ciptaan bersangkutan bisa dibaca oleh orang lain (banyak dilakukan melalui media cetak, misalnya: koran, majalah, terbitan berkala atau bahkan saat ini dikenal dengan media komputer melalui internet);

4. Pengumuman Ciptaan secara langsung atau live, yaitu pertunjukan langsung kepada penonton yang dapat juga disertai dengan siaran langsung melalui media elektronik, misalnya: siaran televisi atau siaran radio, sehingga Ciptaan bersangkutan bisa didengar dan dilihat bahkan bisa dibaca jika ada teksnya;

5. Pengumuman Ciptaan dengan menempelkan pada tempat tertentu, sehingga Ciptaan bersangkutan bisa dilihat dan dibaca oleh orang lain (misalnya: dilakukan dengan baliho atau tempat pengumuman lainnya). (Rooseno Harjowidigdo, 2005: 56)

Sehubungan dengan Ciptaan lagu dan/atau musik dikenal istilah Performing Rights yang dimiliki Pencipta. Arti kata Performing Rights dapat diterjemahkan sebagai hak untuk menampilkan di depan umum atau hak untuk mengumumkan. Sebuah Ciptaan lagu dan/atau musik oleh Penciptanya akan diberikan kepada Produser Rekaman untuk direkam dan selanjutnya akan diedarkan, disebarkan ataupun diperdengarkan. Pada kondisi ini telah terjadi pelaksanaan hak mengumumkan.

Permasalahan yang muncul dalam mengumumkan Ciptaan lagu dan/atau musik ini dimungkinkan tersebar dengan berbagai cara dan tempat, misalnya: di televisi, restoran, gedung bioskop, karaoke, tempat pembelanjaan dan sebagainya. Kondisi mengumumkan ini dapat dilakukan dengan melalui berbagai sarana dan cara, sehingga secara tidak langsung pada saat mengumumkan sekaligus telah terjadi perbanyakan. Makna 'perbanyakan' ini dapat dikatakan bahwa telah terjadi 'penggandaan'. Permasalahan dapat muncul mengingat 
Jurnal Yustika

Vol. 22 No. 1, Jul 2019

Halaman | 47

Peran Lembaga

Manajemen

Kolektif Sebagai

Bentuk

Perlindungan

Hukum Pencipta

Lagu Dan Pemilik

Hak Terkait

Elly Hernawati
Pengguna sebuah Ciptaan lagu dan/atau musik itu beranggapan bahwa mengumumkan itu tidak termasuk memperbanyak atau menggadakan, sehingga Royalti yang dibayarkan hanya berhubungan dengan 'hak mengumumkan' (Performing Rights) saja. Hal ini yang menyebabkan adanyak kesulitan untuk melakukan pengawasan terhadap Ciptaan lagu yang sudah memasuki tahap pengumuman yang telah dilakukan oleh berbagai pihak tanpa ijin dengan secara komersial. Keadaan ini dapat mengakibatkan kerugian bagi Pencipta, Penata Musik atau Pengarasemen maupun Penyanyi dengan lingkup hak masing-masing.

\section{Ad. b. Hak Penggandaan atas Ciptaan.}

Arti kata 'penggandaan' menurut Kamus Besar Bahasa Indonesia adalah: "proses, cara, perbuatan menggandakan". Arti kata 'ganda' adalah: "melipatkan beberapa kali; memperbanyak". Pada Pasal 1 angka 12 UU Hak Cipta 2014 pengertian penggandaan adalah: "proses, perbuatan, atau cara menggandakan satu salinan Ciptaan dan/atau fonogram atau lebih dengan cara dan dalam bentuk apapun, secara permanen atau sementara".

Terkait dengan Ciptaan lagu dan/atau musik dikenal istilah Mechanical Rights yang dimiliki Pencipta. Arti kata Mechanical Rights dapat diterjemahkan sebagai hak untuk menggadakan atau memproduksi kembali. Sebuah Ciptaan lagu dan/atau musik yang digandakan atau diproduksi kembali diwajibkan untuk meminta ijin terlebih dahulu dari Pencipta dan/atau Pemegang Hak Cipta apabila Ciptaan tersebut sudah dialihkan. Pemahaman meminta ijin ini bukan hanya berupa pemberian royalti saja dalam hubungannya dengan Hak Ekonomi, akan tetapi termasuk juga kewajiban untuk mencantumkan nama Penciptanya dalam hubungannya dengan Hak Moral. Selain itu pihak-pihak lain yang berhubungan dengan terwujudnya Ciptaan lagu dan/atau musik tersebut juga harus memperoleh Royalti atas dimanfaatkannya Ciptaan tersebut secara komersial, misalnya: hak Penyanyi, hak Penata Musik atau hak Pengaransemen serta hak Produser Rekaman.

Pihak Pengguna sebuah Ciptaan lagu dan/atau musik, misalnya salah satu contoh: tempat-tempat Karaoke, selain melakukan pengumuman juga telah melakukan penggadaan. Memperdengarkan berulang-ulang sebuah lagu dalam karaoke tersebut, sudah dapat dikatakan telah melakukan 'pengumuman'. Memperbanyak lagu-lagu untuk dimanfaatkan oleh seorang pengusaha karaoke sudah dapat dikatakan telah terjadi 'penggandaan'. Hal ini yang sering menjadikan suatu permasalahan karena sebagian besar pihak Pengguna beranggapan bahwa tempat karaoke itu hanya melakukan 'pengumuman' saja, padahal sebenarnya sekaligus telah melakukan 'penggandaan'. Terlebih bila Pemilik tempat Karaoke tersebut mempunyai lebih dari 1 (satu) tempat Karaoke dan dalam tempat Karaoke tersebut terdapat bermacam-macam ruangan yang dimanfaatkan oleh pengunjung. Hal ini menunjukkan bahwa kegiatan 'pengumuman' dan 'penggandaan' tersebut semakin banyak dan meluas dilakukan oleh pihak Pengguna.

Sehubungan dengan hak mengumumkan dan hak menggadakan tersebut, menjadi kewajiban dari Pengguna Ciptaan lagu dan/atau musik untuk meminta ijin kepada Pencipta atau Pemegang Hak Cipta apabila digunakan secara komersial, hal ini sebagai konsekuensi dari Hak Moral dan Hak Ekonomi yang dimiliki oleh Pencipta atau Pemegang Hak Cipta. Di samping itu sebagai Pengguna juga harus memperhatikan pihak-pihak yang memiliki Hak Terkait, khususnya terhadap Ciptaan lagu dan/atau musik yang digunakan secara komersial, mengingat Pemilik Hak Terkait berdasarkan UU Hak Cipta 2014 di samping memiliki Hak Moral, juga memiliki Hak Ekonomi. Pengertian Penggunaan Secara Komersial berdasarkan 
Pasal 1 angka 24 UU Hak Cipta 2014 adalah: "pemanfaatan ciptaan dan/atau produk Hak Terkait dengan tujuan untuk memperoleh keuntungan ekonomi dari berbagai sumber atau berbayar". Pencantuman atau penyebutan nama Pencipta, Penata Musik atau Pengarasemen pada Ciptaan lagu dan/atau musik yang dimanfaatkan secara komersial itu bukan berarti tidak diperlukan lagi ijin dari Pencipta dan Pemilik Hak Terkait. Konsekuensi dari ijin tersebut sebenarnya ada kewajiban dari pihak Pengguna untuk membayar Royalti kepada Pencipta maupun Pemilik Hak Terkait. Pencipta lagu dan/atau musik memiliki Hak Moral dan Hak Ekonomi. Penyanyi sebagai pihak Pelaku Pertunjukan memiliki Hak Terkait yang terdiri dari Hak Moral dan Hak Ekonomi, Pengarensemen memiliki Hak Moral dan hak Ekonomi atas arensemennya. Pemusik sebagai Pelaku Pertunjukan mempunyai Hak Terkait yang terdiri dari Hak Moral dan hak Ekonomi. Demikian pula Produser Rekaman memiliki Hak Ekonomi atas Ciptaan lagu dan/atau musik tersebut.

\subsection{PERAN LEMBAGA MANAJEMEN KOLEKTIF ATAS HAK EKONOMI PENCIPTA DAN PEMILIK HAK TERKAIT PADA CIPTAAN LAGU DAN/ATAU MUSIK}

Pengertian mengenai Lembaga Manajeman Kolektif terdapat di dalam Pasal 1 angka 22 UU Hak Cipta 2014 sebagai berikut: "Institusi yang berbentuk Badan Hukum Nirlaba yang diberikan kuasa oleh Pencipta, Pemegang Hak Cipta, dan/atau Pemilik Hak Terkait guna mengelola hak ekonominya dalam bentuk menghimpun dan mendistrisbusikan royalti". Terkait dengan keberadaan Lembaga ini, diwajibkan memperoleh ijin operasional terlebih dahulu dengan syarat-syarat sebagaimana tertuang di dalam Pasal 88 UU Hak Cipta 2014 sebagai berikut:

a. Berbentuk badan hukum Indonesia yang bersifat nirlaba;

b. Mendapat kuasa dari Pencipta, Pemegang Hak Cipta, atau Pemilik Hak Terkait untuk menarik, menghimpun, dan mendistribusikan Royalti;

c. Memiliki pemberi kuasa sebagai anggota paling sedikit 200 (dua ratus) orang Pencipta untuk Lembaga Manajemen Kolektif bidang lagu dan/atau musik yang mewakili kepentingan pencipta dan paling sedikit 50 (lima puluh) orang untuk Lembaga Manajemen Kolektif yang mewakili Pemilik Hak Terkait dan/atau objek Hak Cipta lainnya;

d. Bertujuan untuk menarik, menghimpun, dan mendistribusikan Royalti; dan

e. Mampu menarik, menghimpun, dan mendistribusikan Royalti kepada Pencipta, Pemegang Hak Cipta, atau Pemilik Hak Terkait.

Lembaga Manajemen Kolektif yang tidak memperoleh ijin operasional dilarang untuk menarik, menghimpun dan mendistribusikan Royalti.

Sehubungan dengan pengelolaan terhadap Royalti yang dilakukan oleh Lembaga Manajemen Kolektif pada ketentuan Pasal 89 ayat (1)(2) UU Hak Cipta 2014 ditentukan bahwa:

(1) Untuk mengelola Royalti Hak Cipta bidang lagu dan/atau musik dibentuk 2 (dua) lembaga Manajemen Kolektif Nasional yang masing-masing mempresentasikan keterwakilan sebagai berikut:

a. kepentingan Pencipta; dan

b. kepentingan Pemilik Hak Terkait.

(2) Kedua lembaga Manajemen Kolektif sebagaimana dimaksud pada ayat (1) memiliki kewenangan untuk menarik, menghimpun, dan mendistribusikan Royalti dari Pengguna yang bersifat komersial. 
Jurnal Yustika

Vol. 22 No. 1, Jul 2019

Halaman | 49

Peran Lembaga

Manajemen

Kolektif Sebagai

Bentuk

Perlindungan

Hukum Pencipta

Lagu Dan Pemilik

Hak Terkait

Elly Hernawati
Terkait dengan keberadaan Lembaga Manajemen Kolektif tersebut di atas baik untuk kepentingan Pencipta maupun Pemilik Hak Terkait, dalam Peraturan Menteri Hukum Dan Hak Asasi Manusia Nomor 29 Tahun 2014 Tentang Tata Cara Permohonan Dan Penerbitan Izin Operasional Serta Evaluasi Lembaga Manajemen Kolektif (selanjutnya disingkat Peraturan Menteri Hukum Dan Hak Asasi Manusia 2014) pada Pasal 6 menentukan:

LMK Nasional Pencipta dan LMK Nasional Hak Terkait memiliki tugas sebagai berikut:

a. menyusun kode etik LMK di bidang lagu dan/atau musik;

b. melakukan pengawasan terhadap LMK di bidang lagu dan/atau musik;

c. memberikan rekomendasi kepada Menteri untuk menjatuhkan sanksi atas pelanggaran kode etik yang dilakukan oleh pengurus LMK;

d. memberikan rekomendasi kepada Menteri terkait dengan perizinan LMK di bidang lagu dan/atau musik yang berada di bawah koordinasinya;

e. menetapkan sistem dan tata cara penghitungan pembayaran royalti oleh pengguna kepada LMK;

f. menetapkan tata cara pendistribusian royalti dan besaran royalti untuk Pencipta, Pemegang Hak Cipta, dan Pemilik Hak Terkait;

g. melakukan mediasi atas sengketa Hak Cipta dan Hak Terkait;

h. memberikan laporan kinerja dan laporan keuangan kepada Menteri.

Keberadaan Lembaga Manajemen Kolektif setelah berlakunya UU Hak Cipta 2014 merupakan suatu Badan Hukum Nirlaba yang tugas dan tanggung jawabnya membantu Pencipta maupun Pemilik Hak Terkait untuk mengelola Ciptaannya yang berupa lagu dan/atau musik. Prakasa muculnya Lembaga tersebut disebabkan banyaknya pelanggaran terhadap Ciptaan lagu dan/atau musik yang dimanfaatkan pihak lain dengan cara dikomersialkan, sehingga dengan adanya Lembaga tersebut diharapkan dapat mengurangi pelanggaran-pelanggaran Hak Cipta, khususnya Ciptaan lagu dan/atau musik yang dimanfaatkan secara komersial. Sebagaimana diketahui suatu lagu dan /atau musik itu dapat dimanfaatkan oleh masyarakat dengan berbagai cara, hal ini tentunya tidak mudah bagi Pencipta lagu atau Pemilik Hak Terkait untuk memantau pemanfaatan lagu dan/atau musik tersebut termasuk dalam hal pemberian lisensi maupun pemungutan Royalti bahkan dalam hal adanya pelanggaran yang dilakukan oleh masyarakat atas Ciptaan tersebut.

Mengenai pengelolaan Hak Ekonomi terhadap lagu dan/atau musik yang dimanfaatkan secara komersial, dalam hal ini Pencipta, Pemegang Hak Cipta, maupun Pemilik Hak Terkait wajib menjadi anggota dari Lembaga Manajemen Kolektif, agar Lembaga tersebut dapat menarik Royalti terhadap pihak-pihak yang memanfaatkan Ciptaan lagu dan/atau musik yang digunakan secara komersial, hal ini diatur dalam UU Hak Cipta 2014 Pasal 87 ayat (1) menentukan bahwa: "untuk mendapatkan Hak Ekonomi setiap Pencipta, Pemegang Hak Cipta, Pemilik Hak Terkait menjadi anggota Lembaga Manajemen Kolektif agar dapat menarik imbalan yang wajar dari Pengguna yang memanfaatkan Hak Cipta dan Hak Terkait dalam bentuk layanan publik yang komersial". Mengenai pengertian pemanfaatan Ciptaan dan/atau Hak Terkait terdapat di dalam Penjelasan Pasal 87 ayat (4) UU Hak Cipta 2014 menentukan sebagai berikut: "yang dimaksud dengan 'pemanfaatan Ciptaan dan/atau Hak Terkait' meliputi penggandaan untuk kepentingan pengguna secara wajar dan pengumuman".

Pengertian Lembaga Manajemen Kolektif Nasional Pencipta sebagaimana ketentuan dalam Pasal 1 angka 7 Peraturan Menteri Hukum Dan Hak Asasi Manusia 2014 sebagai berikut: “Lembaga Manajemen Kolektif Nasional Pencipta yang selanjutnya disebut LMK Nasional 
Pencipta adalah LMK yang merepresentasikan unsur LMK, Pencipta, Akademisi, dan ahli hukum di bidang Hak Cipta untuk mengelola Hak Ekonomi Pencipta di bidang lagu dan/atau musik". Sedangkan pengertian Lembaga Manajemen Kolektif Nasional Hak Terkait sebagaimana Pasal 1 angka 8 Peraturan Menteri Hukum Dan Hak Asasi Manusia ditentukan sebagai berikut: "Lembaga Manajemen Kolektif yang selajutnya disebut LMK Nasional Hak Terkait adalah LMK yang merepresentasikan unsur LMK, Pemilik Hak Terkait, Akademisi, dan ahli hukum di bidang Hak Cipta untuk mengelola Hak Ekonomi Pemilik Hak Terkait di bidang lagu dan/atau musik".

Lembaga Manajemen Kolektif Nasional untuk kepentingan Pencipta merupakan Lembaga Manajemen Kolektif yang mengelola hak-hak yang dimiliki oleh seorang Pencipta dan/atau Pemegang Hak Cipta untuk kepentingan komersial. Beberapa yang sudah memperoleh ijin operasional adalah: KCI (Karya Cipta Indonesia), WAMI (Wahana Musik Indonesia), RAI (Royalti Anugerah Indonesia). Sedangkan Lembaga Manajemen Kolektif Nasional Hak Terkait merupakan Lembaga Manajemen Kolektif yang mengelola hak-hak yang dimiliki oleh Pemilik Hak Terkait untuk kepentingan komersial. Beberapa yang sudah memperoleh ijin operasional adalah: SELMI (Sentra Lisensi Musik Indonesia), PAPPRI (Persatuan Artis, Penyanyi, dan Pemusik Indonesia), ARDI (Artis Dangdut Indonesia), PRISINDO (Performers' Rights Society of Indonesia), ARMINDO (Anugerah Royalti Musik Indonesia), ASPRINDO (Asosiasi Produser Rekaman Indonesia), ASIRIDO (Asosiasi Industri Rekaman Indonesia)

Siapapun yang memanfaatkan Ciptaan lagu dan/atau musik tersebut wajib membuat perjanjian dengan pihak Lembaga Manajemen Kolektif dengan suatu kewajiban membayar Royalti atas Hak Cipta maupun Hak Terkait yang digunakan tersebut, hal ini tertuang di dalam ketentuan Pasal 87 ayat (2) dan (3) UU Hak Cipta 2014 sebagai berikut:

(2) Pengguna Hak Cipta dan Hak Terkait yang memanfaatkan hak sebagaimana dimaksud dalam ayat (1) membayar Royalti kepada Pencipta, Pemegang hak Cipta, atau Pemilik Hak Terkait melalui Lembaga Manajemen Kolektif".

(3) Pengguna sebagaimana dimaksud pada ayat (1) membuat perjanjian dengan Lembaga Manajemen Kolektif yang berisi kewajiban untuk membayar Royalti atas Hak Cipta dan Hak Terkait yang digunakan.

Sehubungan dengan ketentuan tersebut, seorang Pencipta lagu dan/atau musik harus terlebih dahulu menandatangani perjanjian yang dibuat antara Pencipta atau Pemilik Hak Terkait dengan pihak Lembaga Manajemen Kolektif agar jelas mengenai hak dan kewajiban masingmasing pihak, dan sekaligus adanya pemberian kuasa terhadap Lembaga Manajemen Kolektif untuk melakukan pemungutan Royalti atas Ciptaan lagu dan/atau musik yang dimanfaatkan secara komersial oleh pihak lain. Selanjutnya Lembaga Manajemen Kolektif akan mendistribusikan kepada Pemegang Hak yang sudah melakukan pendaftaran.

Mengenai mekanisme pembayaran Royalti termasuk perhitungannya di dalam UU Hak Cipta 2014 tidak mengaturnya. Peran Lembaga Manajemen Kolektif dalam menarik, menghimpun dan mendistribusikan sesuai dengan UU Hak Cipta 2014 Pasal 89 ayat (3) menentukan sebagai berikut: “Untuk melakukan perhimpunan sebagaimana dimaksud pada ayat (2) kedua Lembaga Manajemen Kolektif wajib melakukan koordinasi dan menetapkan besaran Royalti yang menjadi hak masing-masing Lembaga Manajemen Kolektif dimaksud sesuai dengan kelaziman dalam praktik berdasarkan keadilan". Mengenai ukuran keadilan tidak mudah untuk ditentukan, adil bagi kepentingan Pencipta, akan tetapi tidak adil bagi 
Jurnal Yustika

Vol. 22 No. 1, Jul 2019

Halaman | 51

Peran Lembaga

Manajemen

Kolektif Sebagai

Bentuk

Perlindungan

Hukum Pencipta

Lagu Dan Pemilik

Hak Terkait

Elly Hernawati kepentingan Pemilik Hak Terkait, karena masing-masing pihak baik sebagai Pencipta maupun Penata Musik atau Pengarasemen, Penyanyi, Produser Rekaman, sama-sama mempunyai peranan penting atas terwujudnya sebuah lagu dan/atau musik.

Peraturan Pelaksana yang terkait dengan keberadaan Lembaga Manajemen Kolektif, khususnya Ciptaan lagu dan/atau musik adalah:

1. Peraturan Menteri Hukum Dan Hak Asasi Manusia Nomor 29 Tahun 2014 Tentang Tata Cara Permohonan dan Penerbitan Izin Operasional Serta Evaluasi Lembaga Manajemen Kolektif.

2. Keputusan Menteri Hukum Dan Hak Asasi Manusia Nomor : HKI.2.-OT.03.01-07 Tentang Izin Operasional Lembaga Manajemen Kolektif.

3. Keputusan Menteri Hukum Dan Hak Asasi Manusia Nomor : HKI.2.OT.03.01-02 Tahun 2016 Tentang Pengesahan Tarif Royalti Untuk Pengguna Yang Melakukan Pemanfaatan Komersial Ciptaan dan/atau Produk Hak Terkait Musik dan Lagu.

Peraturan Pelaksana tersebut tidak mengatur mengenai keterlibatan pihak-pihak yang memiliki Hak Terkait atas Ciptaan lagu dan/atau musik, hanya menetapkan mengenai dasar besaran Royalti. Mengenai besaran Royalti dalam Keputusan tersebut ditetapkan secara proporsional dan didasarkan pada best practice (praktek terbaik) yang telah berlaku di Indonesia. Sebagai contoh mengenai besarnya tarif diantaranya sebagai berikut:

a. Kegiatan usaha jasa kuliner bermusik seperti : pub, bar, bistro, besaran royalti ditetapkan per meter persegi per tahun, dengan ketentuan, royalti pencipta sebesar Rp 180.000 per meter persegi per tahun dan pihak terkait sebesar Rp 180.000 per meter persegi per tahun.

b. Kegiatan di rumah bernyanyi atau karaoke, penetapan royalti dibagi 4 (empat) golongan, yakni karaoke tanpa kamar (aula) dengan tarif royalti Rp 20.000 net, karaoke keluarga per kamar dengan tarif royalti Rp 12.000 net, karaoke eksekutif dengan tarif royalti Rp 50.000 net dan karaoke kubus dengan tarif royalti Rp 300.000 per tahun.

c. Kegiatan usaha di bidang diskotek, besaran royalti ditetapkan per meter persegi dengan ketentuan, royalti pencipta $\mathrm{Rp} 250.000$ per meter persegi $\left(\mathrm{m}^{2}\right)$ per tahun dan royalti pihak terkait $\mathrm{Rp} 180.000$ per $\mathrm{m}^{2}$ per tahun.

d. Bidang usaha kuliner bermusik restoran dan kafe, besaran royalti dihitung berdasarkan kursi. Ketentuannya, untuk royalti pencipta dan pihak terkait, besarannya masingmasing Rp 60.000 per kursi per tahun.

e. Kegiatan konser musik. Untuk konser musik bertiket, besaran royaltinya ditetapkan berdasarkan hasil kotor penjualan tiket dikalikan $2 \%$, ditambah dengan tiket yang digratiskan dikalikan $1 \%$. Sedangkan untuk konser musik gratis, royalti dihitung $2 \%$ dari biaya produksi musik.

Penggunaan Ciptaan lagu dan/atau musik yang dimanfaatkan secara komersial, perlindungan hukum yang wajib diberikan oleh Pengguna kepada berbagai pihak-pihak yang terlibat dapat diuraikan sebagai berikut:

1. Pencipta.

Seorang Pencipta sebagai pihak yang memilik Hak Moral dan Hak Ekonomi. Mencipta lagu itu tidak semua orang dapat melakukannya. Dibutuhkan keahlian untuk dapat mencipta sebuah lagu yang merupakan suatu karya intelektual. Keahlian tersebut merupakan anugerah yang diberikan Tuhan Yang Maha Kuasa kepada seorang manusia, sehingga dengan terciptanya lagu tersebut maka setiap orang wajib untuk menghargai dan 
menghomati hak yang dimiliki oleh Pencipta tersebut sebagaimana terdapat dalam Pasal 1 angka 1 dan 2, Pasal 4 UU Hak Cipta 2014.

Jurnal Yustika

Vol. 22 No. 1, Jul 2019

2. Pengaransemen, Penyanyi, dan Pemusik.

Keterlibatan Pengaransemen atas Ciptaan lagu sangat berpengaruh menjadikan lagu tersebut harmoni, indah dan enak didengar. Penyanyi di dalam UU Hak Cipta 2014 termasuk di dalam pengertian Pelaku Pertunjukan sebagaimana ketentuan dalam Pasal 1 angka 6 sebagai berikut: "seorang atau beberapa orang yang secara sendiri-sendiri atau bersama-sama menampilkan dan mempertunjukkan suatu Ciptaan". Seorang Penyanyi atas suatu Ciptaan lagu mempunyai Hak Terkait yang terdiri dari Hak Moral dan Hak Ekonomi. Suatu Ciptaan lagu yang dinyanyikan oleh seorang yang Penyanyi yang tidak profesional, dapat mengakibatkan lagu tersebut tidak diminati masyarakat. Hal ini menunjukkan bahwa seorang Penyanyi itu sangat berpengaruh atas enaknya lagu tersebut saat diperdengarkan. Sehubungan dengan itu pemanfaatan secara komersial suatu Ciptaan lagu dan/atau musik oleh pihak lain, seorang Penyanyi seharusnya mendapatkan royalti. Demikian juga Pemusik, apabila pada saat mengiringi lagu tersebut tidak secara profesional, maka dapat menyebabkan lagu tersebut tidak enak pada saat diperdengarkan.

Ke-tiga pihak tersebut mempunyai Hak Terkait yang meliputi Hak Moral dan Hak Ekonomi sebagaimana ditentukan dalam Pasal 20 huruf a dan b UU Hak Cipta. Hak Moral yang dimiliki itu tidak dapat diabaikan oleh siapapun, hal ini tertuang di dalam Pasal 21 UU Hak Cipta 2014 yang menentukan sebagai berikut: “Hak Moral Pelaku Pertunjukan merupakan hak yang melekat pada Pelaku Pertunjukan yang tidak dapat dihilangkan atau tidak dapat dihapus dengan alasan apapun walaupun Hak Ekonominya telah dialihkan".

3. Produser Rekaman.

Produser Rekaman di dalam ketentuan UU Hak Cipta 2014 disebut dengan istilah Produser Fonogram. Pengertiannya terdapat dalam UU Hak Cipta 2014 Pasal 1 angka 7 sebagai berikut: "orang atau badan hukum yang pertama kali merekam dan memiliki tanggung jawab untuk melaksanakan perekaman suara atau perekaman bunyi, baik perekaman pertunjukan maupun perekaman suara atau bunyi lain". Sebaik apapun lirik lagu atau aransemen lagu, tanpa peran dari Produser Rekaman atau Produser Fonogram yang menjalankan perannya dengan profesional ini, maka akan mengakibatkan lagu tersebut pada saat diperdengarkan tidak akan memberikan hasil yang baik, dan hal ini akan berdampak tidak diminati oleh masyarakat. Dengan kata lain hal ini akan mempengaruhi hak untuk mengumumkan (performing rights) dan hak untuk penggandaan (mechanical rights). Sehubungan dengan itu dalam hal suatu Ciptaan lagu dan/atau musik itu dimanfaatkan oleh pihak lain secara dikomersialkan, maka seharusnya Produser Rekaman juga mempunyai hak atas royalti tersebut.

Munculnya permasalahan pada Ciptaan lagu dan/atau musik tersebut dikarenakan pemahaman bahwa lagu merupakan suatu kesatuan karya cipta yang sifatnya utuh ini masih belum dipahami oleh berbagai pihak, pada umumnya beranggapan bahwa perlindungan hukum terhadap Ciptaan lagu itu lebih mengutamakan kedudukan Penciptanya, artinya pada saat memanfaatkan sebuah Ciptaan lagu secara komersial, cukup memberikan royalti pada Penciptanya saja. Sedangkan keberadaan pihak-pihak yang mempunyai Hak Terkait menjadi terabaikan, padahal Ciptaan lagu itu merupakan suatu karya cipta yang utuh dan melibatkan berbagai pihak yang memiliki Hak Terkait. Meskipun sudah terdapat Lembaga Manajemen Kolektif yang akan melakukan pemantauan terhadap sebuah lagu yang dimiliki oleh Pencipta,
Halaman I 52

Peran Lembaga Manajemen

Kolektif Sebagai Bentuk

Perlindungan

Hukum Pencipta Lagu Dan Pemilik Hak Terkait

Elly Hernawati 
Jurnal Yustika

Vol. 22 No. 1, Jul 2019

Halaman I 53

Peran Lembaga

Manajemen

Kolektif Sebagai

Bentuk

Perlindungan

Hukum Pencipta

Lagu Dan Pemilik

Hak Terkait

Elly Hernawati namun jangkauan pemantauan terhadap lagu yang dimanfaatkan secara komersial tidak mudah dilakukan, terlebih Lembaga Manajemen Kolektif dalam melakukan pemantauan hanya terbatas pada ciptaan-ciptaan lagu dari Pencipta atau Pemilik Hak Terkait yang terdaftar sebagai anggota dari Lembaga Manajemen Kolektif tersebut. Terhadap Pencipta yang tidak terdaftar pada Lembaga Manajemen Kolektif tidak akan mendapatkan pemantauan atas Ciptaan lagu dan/atau musik yang dimanfaatkan secara komersial oleh pihak lain tersebut.

Hubungan hukum antara Pencipta lagu atau Pemilik Hak Terkait dengan Lembaga Manajemen Kolektif telah terakomodir di dalam ketentuan UU Hak Cipta 2014, yaitu adanya ketentuan yang menentukan bahwa untuk mendapatkan perlindungan atas Hak Ekonominya, setiap Pencipta, Pemegang Hak Cipta atau Pemilik Hak Terkait harus menjadi anggota Lembaga manajemen Kolektif. Hanya saja hubungan hukum antara Pencipta dengan Pemilik Hak Terkait misalnya: Pengaransemen, Penyanyi, Pemusik, Produser Rekaman belum terakomodir di dalam UU Hak Cipta 2014, sehingga tidak ada kejelasan mengenai hak dan kewajiban masing-masing pihak atas Ciptaan lagu dan/atau musik tersebut. Seringkali nampak suatu lagu dan/musik itu hanya tercantum nama Penciptanya saja, padahal seorang Pengaransemen atau Pemusik bahkan Penyanyi seringkali terlibat di dalamnya untuk menjadikan suatu lagu dan/atau musik itu menjadi utuh dan indah pada saat didengarkan. Hal ini akan sangat berpengaruh terhadap penyelesaian-penyelesaian atas pelanggaran Ciptaan lagu dan/atau musik yang dimanfaatkan secara komersial oleh pihak lain, karena pihak-pihak tersebut sering terabaikan. Hal ini menunjukkan adanya ketidak pastian hukum mengenai hubungan antara Pencipta dengan pihak-pihak yang membantu terwujudnya suatu lagu. Akibat ketidak jelasan hak dari masing-masing pihak ini, akan sangat mempengaruhi peran Lembaga Manajemen Kolektif di dalam melakukan tugasnya untuk memberikan upaya perlindungan hukum kepada para Pencipta, Pemegang Hak Cipta dan Pemegang Hak Terkait.

\section{Kesimpulan}

Lembaga Manajemen Kolektif mempunyai peranan penting membantu dalam hal pengelolaan dan pendistribusian Hak Ekonomi yang dimiliki oleh Pencipta, atau Pemegang Hak Cipta, dan Pemilik Hak Terkait atas Ciptaan lagu dan/atau musik yang dimanfaatkan oleh pihak lain dengan secara komersial, dengan syarat pihak-pihak tersebut telah menjadi anggota dari Lembaga Manajemen Kolektif. Menurut UU Hak Cipta 2014 peranan Lembaga Manajemen Kolektif hanya untuk kepentingan Pencipta dan Pemilik Hak Terkait.

Peranan Lembaga Manajemen Kolektif terhadap Ciptaan lagu dan/atau musik dari pihak Pencipta, atau Pemegang Hak Cipta, dan Pemilik Hak Terkait ini tidak hanya mencakup performing rights (hak untuk mengumuman), akan tetapi termasuk juga mechanical rights (hak untuk memperbanyak atau menggandakan), mengingat pengumuman yang dilakukan di beberapa tempat oleh Pengguna itu termasuk juga pengertian melakukan perbanyakan atau penggandaan. Mengenai perbanyakan Ciptaan lagu dan/atau musik harus dipahami bahwa makna seijin Pencipta itu bukan hanya mencantumkan nama Penciptanya di dalam Ciptaan yang diperbanyak atau digandakan tersebut, tetapi pengertian seijin Pencipta itu dengan konsekuensi adanya pemberian Royalti kepada Pencipta atau Pemegang Hak Cipta, bahkan kepada Pemilik Hak Terkait.

Hubungan hukum antara Pencipta dengan Pemilik Hak Terkait, khususnya Pengaransemen, Pemusik maupun Penyanyi perlu diatur lebih jelas, mengingat pihak-pihak tersebut merupakan pihak yang sangat membantu terwujudnya suatu lagu dan/atau musik 
menjadi suatu karya Cipta yang utuh. Ketidak jelasan dalam hak masing-masing akan dapat mempengaruhi peran Lembaga Manajemen Kolektif dalam menjalankan tugasnya sebagai upaya perlindungan hukum kepada para Pencipta, Pemegang Hak Cipta maupunh Pemilik Hak Terkait.

\section{Daftar Referensi}

Bernard Nainggolan. (2016). Komentar Undang-Undang Hak Cipta. Jakarta: Alumni.

Candra Irawan. (2011). Politik Hukum Hak Kekayaan Intelektual Indonesia. Bandung: Mandar Maju

Henry Soelistyo. (2011). Hak Cipta Tanpa Hak Moral. Yogyakarta: Radjawali Pers. PT Radjagrafindo Persada.

Husain Audah. (2004). Hak Cipta dan Karya Cipta Musik. Jakarta: Litera AntarNusa.

Rahmi Jened.(2014). Hukum Hak Cipta (Copyright's Law). Bandung: Citra Aditya Bakti.

Rooseno Harjowidigdo. (2005). Perjanjian Lisensi Hak Cipta Musik Dalam Pembuatan Rekaman. Jakarta: Perum Percetakan Negara RI.

Otto Hasibuan. (2014). Hak Cipta Di Indonesia. Tinjauan khusus Hak Cipta Lagu, Neighbouring Rights dan Collecting Society. Bandung: PT.Alumni.

Dini Destama. (2010). Harmoni. https://www.kompasiana.com. [diunduh 14 Agustus 2018]

Landasanteori.(2015). Hak Eksklusif Pemegang Hak Cipta Lagu dan Musik. https://www.landasanteori.com. [diunduh 13 Agustus 2018]

Senibudayaku. (2017). Pengertian Aransemen Lagu dan Seni Membuat Aransemen. https://www.senibudayaku.com. [diunduh 14 Agustus 2018] 